International Journal of Social Science And Human Research

ISSN(print): 2644-0679, ISSN(online): 2644-0695

Volume 04 Issue 05 May 2021

DOI: 10.47191/ijsshr/v4-i5-23 Impact factor-5.586

Page No : 1068-1073

\title{
Blockchain Technology - Towards Complementing the Structuring of Sukuk: A Literature Review
}

\author{
Nadhirah Sakinah Binti Sidik ${ }^{1}$, Azlin Alisa Ahmad ${ }^{2}$ \\ ${ }^{1,2}$ Research Centre for Shariah, Faculty of Islamic Studies, 43600 Universiti Kebangsaan Malaysia, Bangi, Selangor, Malaysia
}

\begin{abstract}
Blockchain is a new innovative technology that offers various benefits to society because it can be applied in various industries, including the financial industry. Several issues have arisen concerning sukuk practices in Malaysia, some of which are default payments, ambiguous risks, publishing process, lengthy transactions and high costs. In line with the digitalisation era, blockchain technology has the capability to improve the present sukuk structure in Malaysia by applying its characteristics to make the sukuk structure more efficient because sukuk plays an important role in a nation's development and progress. However, sukuk is vulnerable to various risks. Therefore, this study is a preliminary survey aimed at identifying issues pertaining to sukuk, capability of blockchain technology and how this technology can complement the structuring of sukuk in Malaysia. This qualitative literature review study used the document analysis method to collect data. Findings show that the blockchain technology's characteristics enables it to improve the structure of sukuk as well as complement and become a new addition to the Islamic capital market in Malaysia. This study hopes to contribute to the existing corpus of knowledge in all levels of society, especially those directly involved in sukuk, so that the sukuk market continues to expand with the times as well as contribute to the nation's progress and comply with Shariah principles.
\end{abstract}

KEYWORDS: Technology, Blockchain, Sukuk, Efficient, Shariah

\section{INTRODUCTION}

Advancements in technology in the present digitalisation era has created various new technologies that benefit numerous sectors. Among the new technologies that are increasingly and rapidly expanding as well as widely applied at the international level is blockchain (Zarinah 2017). Concordant with the Industrial Revolution 4.0 (IR 4.0) movement, Malaysia's Islamic Financial Industry needs to take advantage of the blockchain technology for enhancing the national economy by diversifying the services offered so that it moves in line with current developments. Blockchain is a product of combining technology and innovation, and it has a huge potential to progress further when it is adopted by the Islamic capital market, specifically sukuk. The advantage of blockchain technology is apparent in aspects such as lower operational costs, greater competitiveness, user-friendly, concise, safe as well as provide better performance (Finyear 2018).

Sukuk is another alternative for replacing conventional bonds and it is based on Islamic Syariat principles that are free from usury, gambling, gharar (uncertainty or risk) and other elements that contradict Islamic Syariat. This feature differentiates sukuk from conventional bonds. The sukuk market has successfully expanded rapidly compared to conventional bonds and has contributed towards enhancing the nation's economy, mainly in Malaysia. Malaysia is the leader in the Islamic capital market, namely involving sukuk (Berita Harian, 2020). Sukuk is an Islamic financial instrument used to collect funds or capital according to Shariah principles and then the funds or capital are transferred based on the contract related to the sukuk, which is either the government or a company, in order to develop a project. This shows that sukuk is an Islamic investment that involves large scale projects. Therefore, sukuk is exposed to various issues, risks etc.

Blockchain technology can complement the sukuk market through the characteristics of the blockchain itself and it is in accordance with Shariah principles. The Islamic financial industry can provide better services if the society can accept blockchain technology with an open mind, form collaborations and invest in order to create products and services using blockchain technology. This is because the blockchain technology revolution has positive effects on the quality of the labour market and financial sector in a country. The one who receives the most benefits are the clients because it helps them obtain better products with reasonable prices. Thus, it is important for the Islamic financial industry in Malaysia to evaluate blockchain technology related to sukuk for the sake of the nation's stability and economic progress. 


\section{Blockchain Technology - Towards Complementing the Structuring of Sukuk: A Literature Review}

\section{THE BLOCKCHAIN TECHNOLOGY CONCEPT}

Blockchain is a technology that is fully accessed online and functions by recording all business transactions and safely stores data in a virtual manner (Alam et.al 2019). Nugraha (2020) stated that blockchain technology is the implementation of internet-based technology. The type of relationship between one block and another is linked and it is distributed to millions of computers all over the world, which makes information in the blockchain technology impervious to hacking by outside parties (Nabihah 2018). Any change to the blockchain technology requires the consensus of all the links that form the network in the blockchain technology. Moreover, every blockchain technology user can see the same data and information that is posted (Khalid 2018). This makes blockchain technology concise and transparent (Khan et. al 2020). Transparency plays an important role as a measure of Syariah compliance in every transaction carried out (Shaikh \& Zaka 2019). Decentralised data storage also increases the privacy level of the data and transparency of a transaction in blockchain technology because every individual that has a link to blockchain technology possesses information about the data. Indirectly, this makes all data and transactions in the blockchain technology more transparent, accurate, consistent, traceable and safe (Zaipul 2019).

Blockchain is a type of technology that can be programmed or set (Maghdeed 2019). Blockchain technology is divided into three categories, namely public, private and hybrid or also known as a consortium. Each category has different characteristics (Elasrag 2019).

i. Public blockchain is a block network that does not have a sole owner and all consumers who use the public blockchain have equal rights to observe the system and review or update the system. One example of public blockchain is bitcoin.

ii. Private blockchain is a personal block network that is limited only to entities that use the private blockchain to control and update a system.

iii. Hybrid blockchain is generally a network of blocks but its use is limited to part of the entity that uses the hybrid blockchain. A system is only managed by part of the party but the whole entity that uses hybrid blockchain can observe the system in process.

This allows the development of the blockchain technology, model and Islamic financial structure by providing products and services that fulfil Shariah principles as an alternative to fulfilling the consumer's needs and preferences, especially a Muslim consumer.

\section{APPLYING BLOCKCHAIN TECHNOLOGY IN ISLAMIC FINANCES}

Blockchain is a technology that is found in fintech. The Islamic Financial Industry would benefit from the potential that exist in fintech in order to enhance the services and products offered concordant with the digitalisation era (Nabilah et.al 2018). Mohamad Sofee (2020) stated that the current use of fintech in the conventional system is expanding at a tremendous pace but is rather lackadaisical in the Islamic financial sector (Berita Harian, 2020). The emergence of fintech in the Islamic financial system makes it more competitive and potentially favourable, as evidenced in assets valued at USD3.9 trillion or RM16.3 trillion in 2023 (Metro, 2019).

The application of fintech in Islamic finances is an advantage to the Islamic financial industry (Akram \& Fares 2019). This strongly indicates that blockchain technology has benefits if it is applied in Islamic finances. This statement is supported by Eka et. al (2020), who stated that reaping the benefits of blockchain technology in the crowdfunding platform can help to record and protect transaction data in a more transparent and concise manner, which could help avoid fraud (personal gains).

Crowdfunding is one of the platforms for collecting funds quickly through the internet and channelling it to those who need it or into a fund for a development project. The use of blockchain technology for managing zakat could consolidate the zakat management and services system in Malaysia (Nabilah et. al 2018).

Blockchain technology can also provide benefits to other fields. One of the benefits is recording all forms of agreements or transactions by the government in order to avoid corruption, fraud, smuggling etc. (Probank 2017). Applying blockchain technology to the education field could also provide benefits, such as preventing activities related to falsification of degree certificates (Untung et. al 2020). This finding supports a previous study by Nabilah et. al (2018), who observed that Universiti Malaysia Pahang (UMP) had used blockchain technology to expediate the management system by authenticating a student's certificate and monitoring the cashless payment system (e-wallet) used for purchasing necessities in campus. In addition, the world is presently experiencing the Covid-19 pandemic, which has restricted human movement and communication and this technology can play a significant role.

However, blockchain technology allows all data records and transactions to be accessed from various locations (Rita 2020). Fajar et. al (2021) found that blockchain technology can also be applied to the field of agriculture. This technology increases the efficiency and promptness of the agricultural management system, minimises the role of brokers, nurtures well-being and provides profits to farmers as well as allows authorities to monitor the prices of some of the agriculture products that influence inflation. This strongly indicates that blockchain technology can pose benefits to various fields. The adoption of blockchain technology by various fields is still new in Malaysia and the benefits have not been fully appreciated mainly because the knowledge and 


\section{Blockchain Technology - Towards Complementing the Structuring of Sukuk: A Literature Review}

understanding of the concept and ensuing benefits are still vague and doubtful. Moreover, blockchain is frequently misunderstood by society for bitcoin. Undeniably, blockchain technology has become better known through bitcoin, which was founded by Satoshi Nakamoto, but the functions of blockchain and bitcoin are different (Sherin et. al 2020).

\section{SUKUK PRACTICE IN MALAYSIA}

Generally, sukuk is defined as a valuable certificate issued by a Special Purpose Vehicle (SPV) to certify the ownership of an asset and the rights to the benefits accruing from the asset (Finyear 2018). There are four types of sukuk in Malaysia, namely sales-based, lease-based, agency-based and partnership-based sukuk (Azam et. al 2018), which are moulded according to the Syariah concept and applied in each sukuk product. There are various Syariah concepts that can become the basis for a sukuk published in Malaysia. Among the concepts listed by the Securities Commission of Malaysia are ijarah, ijarah thumma bai', musharakah, mudharabah, murabahah, musawamah, qardh hasan, tawarruq, wakalah, istisna', bai' wafa', bai' salam, bai' inah, bai' istijrar and bai' bithaman ajil (SC 2019). Azam et. al (2018) stated that sukuk in the form of ijarah, murabahah, bai' bithaman ajil, mudharabah, musharakah and bai' inah are among the most frequently applied sukuk in Malaysia's Islamic capital market. All these sukuk are based on two structures, namely asset-based and asset backed (Dzubaidah \& S. Shahida 2013). Azam et. al (2018) also stated that there are three structures currently in the sukuk market, which are the asset-based, asset backed and hybrid structures.

Therefore, diverse products in the sukuk market will continue to rapidly expand sukuk in line with the vigorous Islamic capital market, especially in Malaysia. These diverse products in the sukuk market indicate the uniqueness of sukuk compared to conventional bonds (Sherin et. al 2020). Nursilah and Syazwani (2014) mentioned in their study entitled Investigating Stock Market Reactions on Sukuk Issuance Based on Ratings that the sukuk market has lately saw a rapid expansion although the size of the market is still considered moderate at the global level but its growth has been very encouraging. Balkish et al. (2012) and Mohamad and Saad (2012) also strongly suggested that sukuk has expanded to become the main mechanism for capital procurement in the market through methods recognised by Islam Syariat. In addition, Azam et. al (2018) stated that Malaysia was one of the earliest countries to seek verification from the relative agencies for an authoritative credit rating in order to publish sukuk in Malaysia. Undoubtedly, this step has a positive impact on the sukuk market because it helps publishers and investors in making evaluations before publishing or investing in a sukuk structure. Syariah-compliance must be emphasised from various aspects when structuring sukuk. The first aspect is the use of funds accruing from the publishing of sukuk. The use of funds by the publisher and the subsidiaries must be Syariah-compliant.

The second aspect is the underlying asset in the sukuk. This is needed to facilitate the publishing of sukuk, which must be free from financial services that are based on usury ( $r i b a$ ), gambling, producing non-halal products and other activities that are not Syariah-compliant (Dzubaidah \& S. Shahida 2013). However, Finyear (2018) stated that there are still criticisms regarding the publishing and returning process in sukuk. Some of the criticisms concern non-Syariah compliance in the structuring of sukuk, a complicated publishing process, involvement of too many parties, high costs and default payments in sukuk. Dzubaidah and S. Shahida (2013) recorded 24 cases concerning default payment in sukuk throughout the 8-year period from 2002 to 2010. Meanwhile, Azizur dan Mansor (2017) found that caring for underlying assets or cash flow requires strict focus on sukuk so that appropriate action can be taken, such as taking corrective measures promptly. This can be determined and monitored by tracking underlying assets. The study explained that underlying assets are among the main elements that ensure whether a sukuk transaction is Shariah-compliant. Thus, detecting the underlying asset helps to reduce exposure to several risks that could jeopardise a sukuk transaction. Among the risks associated with sukuk are default payments related to the underlying asset or profits accruing from a project. This occurs because of the inability to manage the published sukuk. According to Azizur and Mansor (2017), sukuk must involve a true sale so that the SPV can easily manage and use the underlying asset in case of a default in payment, in which the company is unable repay the invested amount to the investor. Hence, this requires the element of transparency and clarity in each sukuk transaction.

Some views mention that in order to avoid risks, disclosure about sukuk products is critical and a prerequisite for safeguarding the benefits of the sukuk product and this encourages transparency in sukuk transactions, while dismissing criticisms about the sukuk market. Non-transparency can cause default in payments, which causes losses to investors and this should be avoided in each sukuk structuring model. This element and method could attract non-Muslims to the Islamic capital market (Azizur \& Mansor 2017). Alam et.al (2013) studied the impact on the wealth of sukuk holders from 2004 to 2012 and mentioned that Shariahcompliance and maqasid shariah concepts should be further strengthened when publishing sukuk so that the issue of default payment can be solved. Some views mention that the development of sukuk products should consider the issue of legal costs that tend to increase the overall costs when creating an Islamic product. The Securities Commission (2019) had stipulated a condition whereby institutions that publish sukuk must appoint their own Syariah advisors, which will inevitably increase the overall cost of publishing sukuk. This does not encourage the development and growth of Islamic products (Azizur \& Mansor 2017). Hence, the practice of sukuk in Malaysia should be further improved in order to overcome these issues. 


\section{Blockchain Technology - Towards Complementing the Structuring of Sukuk: A Literature Review}

\section{SUGGESTIONS FOR USING BLOCKCHAIN TECHNOLOGY IN SUKUK}

Based on the characteristics of blockchain technology as mentioned earlier, this study found that the Islamic capital market, especially sukuk, must reap the benefits of blockchain technology. Maghdeed (2019) stated that blockchain technology is a solution to issues concerning the Islamic capital market, specifically sukuk, because it enables sukuk to enhance transparency in transactions involving underlying assets, prevent risks related to default payments and enhance the nation's economy (Finyear 2018). This finding is supported by Sherin et. al (2020), who found that blockchain technology can reduce costs, exposure to risks, is a fast-publishing process, a 24-hour operations system, and increases the level of trust in investors. Transparent transactions can be guaranteed when using blockchain technology because transaction data are circulated in computers that have a blockchain network similar to data possessed by the individual who is carrying out the transaction. Data in blockchain technology cannot be amended unless that is an agreement or consensus between all the users in the blockchain network (Zaipul 2019). This allows the blockchain technology to guarantee the safety of the data from being hacked by others. Moreover, the use of blockchain technology can reduce sukuk security risks because a study by Azian (d.u.) found that the challenge of sukuk security is higher compared to conventional bonds. Hence, blockchain technology is not only a safe technology but also a technology offering numerous advantages that can be benefitted from in order to complement the structuring of sukuk currently available in Malaysia. Findings of previous studies show that sukuk had expanded and has become an Islamic financial instrument that is gaining in importance everyday in the Islamic capital market in Malaysia as well as all over the world. Technological advancement is expanding according to the current flow consistent with human needs. Hence, there are several items in sukuk that need to be emphasised, one of which is the flow in tandem with contemporary developments. This could also contribute towards enhancing the quality of the product and the sukuk market located in the Islamic capital market. Applying blockchain technology to sukuk can help solve various problems concerning sukuk, either related to the publishing process, transactions, Syariah-compliance etc. because there are numerous advantageous and benefits of blockchain, one of which is a safer, more accurate and transparent sukuk data. Transparency is an important element in ensuring whether a product is Syariah-compliant, which would then help reduce sukuk publishing costs, transaction costs and save time (Khan et.al 2020). The effectiveness of blockchain technology is evident in the platform provided by Finterra, which is aimed at the management of wakaf using blockchain technology. This initiative can enhance the level of transparency, reduce errors, enhance the management quality and indirectly enhance its efficiency (Khalid 2018).

The element of traceability can also increase investors' confidence in sukuk, which uses blockchain technology (Shaikh \& Zaka 2019). All information related to transactions are well recorded and conveyed quickly and efficiently, while risks and problems are identified promptly, leading to savings in time and costs (Untung et.al 2020), which is all attributed to the use of online facilities by the blockchain technology. Blockchain technology is not a centralised system and it is a technology that can be programmed. Shaikh and Zaka (2019), in their qualitative study entitled Blockchained Sukuk-Financing, stated that the use of blockchain technology in sukuk can bridge the gap between sukuk investors. Khalid (2018) found four unique features in blockchain technology, namely the efficient and prompt processing of transactions, a decentralised network, safety of data, and transparent transactions. This finding was supported by Hamza (2020), who mentioned that among the advantages of blockchain technology in structuring sukuk is that is can be accessed by many students, expand the sukuk market, has the capability to process quickly, concisely and transparently, low transaction costs, facilitates the audit process, minimises the operational process, such as requirements mentioned in documents, signatures and others, and 24-hour operations, which could expand the sukuk market. The study also found some weaknesses in the application of blockchain technology for structuring sukuk, such as being an underdeveloped technology, high capital costs, difficulty in adaptation by the society, lack of pertinent legislature and software issues.

Therefore, a study on the capability of blockchain technology to complement the structuring of sukuk in Malaysia should be conducted to determine the pros and cons of blockchain technology. Based on previous studies, there is still a gap as these studies have not touched upon the capability of blockchain technology to complement the structuring of sukuk in Malaysia. This is because there is a great potential that can be fulfilled by blockchain technology in the management of sukuk. Besides that, Malaysia provides a huge avenue and opportunity to apply blockchain technology in the management of sukuk because Malaysia has an industry, such as Finterra, that can collaborate in efforts to realise the application of blockchain technology in the structuring of sukuk because Finterra is a company that develops blockchain technology. Hence, this study intended to determine whether blockchain technology can complement the structuring of sukuk in Malaysia. The use of blockchain technology for this purpose is not aimed at eradicating traditional sukuk but will diversify the current sukuk product, besides responding to the government's challenge to produce sustainable finances.

\section{CONCLUSION}

This preliminary survey study on blockchain technology involved a literature review related to the structuring of sukuk in Malaysia. Findings show that concordant with the current digitalisation era and the new norm, blockchain technology has the 
capability to complement the current sukuk market in Malaysia. Adoption of the blockchain technology by the Islamic financial industry, especially sukuk, can help form transactions that are comprehensive, transparent, prompt, efficient and Syariatcompliant. This is because, currently, there are various sukuk applications in different products and most of them apply sukuk in markets that involve a huge value. Hence, the implementation of sukuk should be emphasised and reviewed in order to avoid the abuse of sukuk by irresponsible parties as well as avoid creating issues in the structuring of sukuk, mainly in Malaysia.

Malaysia is one of the pioneers of sukuk and its market value has successfully enhanced Malaysia's economy. Therefore, blockchain technology plays a significant role in the structuring of sukuk as it can help maintain performance and strengthen the sukuk market, besides avoiding losses or credit incapacity in the structuring of sukuk in Malaysia.

\section{REFERENCES}

1) Ahmad Azam Sulaiman, Muhammad Haffiz \& Nur Maizatul Dina. 2018. "Sukuk Credit Rating" Di Malaysia: Perbandingan di antara RAM dan MARC. Labuan E-Journal of Muamalat and Society.

2) Anon. 2017. Majalah Probank. Jakarta: Perbanas.

3) Azian Madun. t.t. Cabaran Pensekuritian Sukuk dalam Sistem Kewangan Islam. t.p.

4) Dzubaidah Zainal Abidin \& S.Shahida. 2013. Sukuk "Asset-Based" Berbanding Sukuk "Asset-Backed": Kes Kemungkiran Sukuk. Prosiding Perkem VIII, 574-585.

5) Eka Purnama Harahap, Qurrotul Aini \& Reza Khaerul Anam. 2020. Pemanfaatan Teknologi Blockchain pada Platform Crowdfunding. Technomedia Journal.

6) Elasrag, Hussein. 2019. Blockchain for Islamic Finance: Obstacles \& Challenges. MPRA Paper No. 92676.

7) Fajar Delli Wihartiko, Sri Nurdiati, Agus Buono \& Edi Santosa. 2021. Blockchain dan Kecerdasan Buatan dalam Pertanian: Studi Literatur. Jurnal Teknologi Informasi dan Ilmu Komputer.

8) Finyear. 2018. The Future of Banking: Blockchain May be the Sukuk Industry's Missing Link. 24 Oktober.

9) Hamza, Osama. 2020. Smart Sukuk Structure from Sharia Perspective and Financing Benefits: Proposed Application of Smart Sukuk through Blockchain Technology in Islamic Banks within Turkey. European Journal of Islamic Finance.

10) Maghdeed, Farhang. 2019. SukukChain: A Blockchain Solution for Islamic Capital Markets. MIA, 14 Ogos.

11) Metro. 2019. Fintech Tingkat Capaian Perniagaan, Pelanggan. 14 Oktober.

12) Mohamad Akram Laldin \& Fares Djafri. 2019. Kewangan Islam dalam Dunia Digital: Peluang dan Cabaran. Journal of Islam in Asia.

13) Mohamad Sofee Razak. 2020. Perluas Potensi Fintech dalam Kewangan Islam. Berita Harian, 7 September.

14) Nafis Alam, M. Kabir Hassan \& Mohammad Aminul Haque. 2013. Are Islamic Bonds Different From Conventional Bonds? International Evidence from Capital Market Tests. Borsa Istanbul Review, 22-29.

15) Nafis Alam, Lokesh Gupta \& Abdolhossein Zameni. 2019. Fintech and Islamic Finance Digitalization, Development and Disruption. Switzerland: Springer Nature.

16) Nida Khan, Bilal Kchouri, Nissar Ahmad Yatoo, Zsofia Kräussl, Anass Patel \& Radu State. 2020. Tokenization of Sukuk: Ethereum Case Study. Global Fianance Journal.

17) Nor Balkish Zakaria, Mohamad Azwan \& Rabiatul Adawiyah. 2012. "The Construct of Sukuk, Rating and Default Risk", International Congress on Interdisciplinary Business and Social Science 2012. Procedia Social and Behavioral Sciences.

18) Nugraha, Ade Chandra. 2020. Penerapan Teknologi Blockchain dalam Lingkungan Pendidikan. Jurnal Produktif.

19) Nursilah Ahmad \& Syazwani Abd Rahim. 2014. Investigating Stock Market Reactions on Sukuk Issuance Based on Ratings. Prosiding $4^{\text {th }}$ International Conference on Business and Economic Research (4 ${ }^{\text {th }}$ ICBER 2013).

20) Rita Komalasari. 2020. Manfaat Teknologi Informasi dan Komunikasi di Masa Pandemi Covid 19. Jurnal Teknologi Informasi dan Komunikasi.

21) Shazib Shaikh \& Fatima Zaka. 2019. Blockchained Sukuk-Financing. Conference Paper. link.springer.com.

22) Sherin Kunhibava, Zakariya Mustapha, Aishath Muneeza, Auwal Adam Sa'ad \& Mohammad Ershadul Karim. 2020. Sukuk on Blockchain: A Legal, Regulatory and Shariah Review. ISRA International Journal of Islamic Finance.

23) Siti Nabilah Esrati, Shifa Mohd Nor \& Mariani Abdul Majid. 2018. Fintech (Blockchain) dan Pengurusan Zakat di Malaysia. Prosiding Persidangan Kebangsaan Ekonomi Malaysia Ke 13.

24) Siti Zarinah Sahib. 2017. Perkenal Malaysia Menerusi Blockchain. Hmetro. 23 Jun.

25) Suruhanjaya Sekuriti. 2019. Keputusan Majlis Penasihat Syariah Suruhanjaya Sekuriti Malaysia.

26) Syed Khalid Rashid. 2018. Potential of Waqf in Contemporary World. Journal of King Abdulaziz University Islamic Economics.

27) Untung Rahardja, Eka Purnama Harahap \& Dennies Dwi Christianto. 2020. Pengaruh Teknologi Blockchain Terhadap Tingkat Keaslian Ijazah. Technomedia Journal. 


\section{Blockchain Technology - Towards Complementing the Structuring of Sukuk: A Literature Review}

28) Untung Rahardja, Qurotul Ain, M. Yusup \& Aulia Edliyanti. 2020. Penerapan Teknologi Blockchain Sebagai Media Pengamanan Proses Transaksi E-Commerce. Journal of Computer Engineering System and Science.

29) Zaipul Anuar Zainu. 2019. Apakah Teknologi Blockchain? MelakaKini. 